\title{
Effect of phytochemicals on quality and safety aspects of meat and meat products
}

\author{
O. Biswas ${ }^{1}$, P. Kandasamy ${ }^{1}$, S. Patnaik ${ }^{2}$, J. M. Lorenzo ${ }^{3,4}$ and A. K. Das ${ }^{5 *}$ \\ ${ }^{1}$ Department of Agricultural Engineering, Institute of Agriculture, Visva-Bharati (A Central \\ University), Sriniketan - 731 236, West Bengal, India; ${ }^{2}$ Deparment of Livestock Product Technology, \\ West Bengal University of Animal and Fishery Sciences, Kolkata - 700 037, West Bengal, India; \\ ${ }^{3}$ Centro Tecnológico de la Carne de Galicia, Rúa Galicia No 4, Parque Tecnológico de Galicia, San \\ Cibrao das Viñas, 32900 Ourense, Spain; ${ }^{4}$ Área de Tecnología de los Alimentos, Facultad de Ciencias \\ de Ourense, Universidad de Vigo, 32004 Ourense, Spain; ${ }^{5}$ Eastern Regional Station, ICAR- Indian \\ Veterinary Research Institute, Kolkata - 700 037, West Bengal, India
}

\begin{abstract}
Fresh and processed meat products provide a variety of nutritional and health benefits, as well as distinct eating satisfaction. The most important aspects of meat preservation, quality, and safety are to prevent microbiological deterioration and lipid oxidation reactions, as well as to protect the meat from deterioration in taste and texture. Synthetic preservatives were widely used in the meat industry to check lipid oxidation and control the growth of spoilage and harmful microbes, hence extending the shelf-life, quality, and safety of meat products. Consumer demands for a more ethical, healthful, and ecologically friendly food supply to feed the world's growing population have prompted this shift in focus. A summary of research on the direct inclusion of natural preservation agents into meat and meat products, to enhance shelf life is presented. The development of edible packaging materials incorporating natural preservatives is accelerating, and this review paper highlights the applicability of few selected preservatives in a variety of meat products.
\end{abstract}

Key words: Antimicrobials, Antioxidants, Bioactives, Meat products, Phytochemicals

\section{Highlights}

- Phytochemicals have diverse biological activities like antioxidants and antimicrobials.

- Phytochemcials improve the quality, and safety of meat products.

- Phytochemcials influence the sensory acceptability of meat products.

- Phytochemcials enhance the shelf life of meat and meat products.

- Phytochemicals could be used as best food preservatives alternative to synthetic counterparts.

\section{Introduction}

Meat and meat products are perishable foods due to their high nutritional content, moisture content, and neutral $\mathrm{pH}$. These foods must be properly preserved to ensure quality and safety and prevent human illness and disease epidemics. Oxidation and microbial degradation are the limiting factors in the quality and acceptability of meat products that deteriorate the taste, colour, texture, and nutritional content (Das et al., 2020). In recent years, meat product manufacturers have seen an increase in consumer demand for higher- quality, healthier meats, particularly totally natural, less processed, and ready-to-use products with specific additive labeling. Multiple synthetic additives have been utilised in recent years to inhibit the limiting factors and extend the shelf life of meat and meat products during refrigerated storage. Various studies have demonstrated that synthetic chemicals such as butylated hydroxytoluene (BHT) and butylated hydroxyanisole (BHA) produce various carcinogenic and toxic reactions, leading to an increase in customer concern and desire for healthier meat products that use

"Corresponding Author, E Mail: arun.das@icar.gov.in 
natural rather than synthetic preservatives (Aminzare et al., 2016). The meat industry was inclined to explore natural alternatives that have high antibacterial and/or antioxidant qualities to satisfy customer demands and restore public confidence in the safety of food items. To improve the shelf-life and safety of food products, plant extracts and essential oils, enzymes, peptides, chitosan, bacteriocins, fermented substances can all be utilized as potential alternatives to synthetic antibacterial agents. Vitamins, herbs, spices, and plant extracts contain antioxidant components and may be used as natural antioxidant agents to inhibit lipid oxidation in food products (Aziz and Karboune, 2018). Some natural antioxidants/antimicrobials have been discovered to not only be capable of extending the shelflife of meat products, but also to be effective as preventative medication against a variety of human ailments (Shah et al., 2014; Das et al., 2020). Therefore, many investigations have been carried out in an effort to substitute natural preservatives for synthetic preservatives in meat and meat products.

\section{Lipid oxidation in meat and meat products}

Lipo-peroxidation in meat and meat products is impacted by various factors, including fatty acid composition, presence of high amounts of salt pro-oxidant agents and myoglobin found in muscles; the polyunsaturated fatty acids contained in the phospholipids, as well as the $\alpha$ - tocopherol content, are the main targets of oxidative rancidity (Ribeiro et al., 2019). The development of off-flavor, discoloration, formation of hazardous chemicals, loss of nutrients, and drip losses occur as a result of oxidative rancidity of meat and meat products, shortening the shelf life; further, making it unsuitable for human consumption. Lipid oxidation is a multi-step process; involving numerous processes, that interact with one another. Unsaturated fatty acids react with molecular oxygen via a free radical process and produce hydroperoxides, the earliest oxidation products. Hydroperoxides, unlike other lipid- derived compounds, are highly unstable, odourless, and do not contribute any aroma. They breakdown quickly, producing a huge variety of secondary chemicals such as hydrocarbons, aldehydes, ketones, alcohols, esters, and acids, which contribute to the emergence of off-flavors and off-odors in meat (Domínguez et al., 2019). Aldehydes, particularly hexanal, are the principal cause of off-odors in oxidised meat. Lipid oxidation leads to protein oxidation and discolours meat by oxidising heme pigments and reduces protein solubility and water holding capacity. Protein oxidation reduces protein solubility and water holding capacity, both of which are critical for meat processing. Lower protein holding capacity makes the meat dry due to higher moisture loss during heating (Huang and Ahn, 2019). Cooked meats are more prone to lipid oxidation than raw meat, as higher temperatures trigger the release of oxygen and heme, iron, resulting in the generation of free radicals which are responsible for the development of off-odors and off-flavors. These flavours are referred to be 'warmed-over flavor' because they become more noticeable after the meat has been reheated. This is a huge challenge for the industry, because consumers are increasingly valuing ready-to-eat convenience items (Amaral et al., 2018). Lipid oxidation and myoglobin oxidation in meat products are interlinked, and both reactions appear to be able to influence one another. The oxidation of oxymyoglobin produces metmyoglobin and $\mathrm{H}_{2} \mathrm{O}_{2}$, which are required for lipid oxidation. Aldehyde lipid oxidation products, on the other hand, modify myoglobin redox stability, resulting in increased oxymyoglobin oxidation and the development of a covalent adduct with myoglobin (Chaijan, 2008). Lipid hydrolysis can occur enzymatically or non-enzymatically in meat. Lipolysis is the enzymatic hydrolysis of fats that is mediated by specific enzymes such as lipases, esterases, and phospholipase. Lipases breakdown the glycerides during lipolysis, forming free fatty acids, which are responsible for the off-flavor commonly, referred to as rancidity. Phospholipase $A_{1}$ and 
phospholipase $\mathrm{A}_{2}$ are the most important enzymes involved in meat lipid breakdown (Dave and Ghaly, 2011). Therefore, the meat and poultry industry is aiming actively to minimize oxidative rancidity and improve nutritional quality by incorporating antioxidants from natural sources as a substitute to the currently used conventional antioxidants.

\section{Microbial deterioration of meat and meat products}

Meat and meat products are highly perishable foods with high nutritive content that support rapid microbial growth. Microorganisms are the most common cause of degradation of the quality of meat products. The spoilage microbes decompose fat, carbohydrate, and protein in meat, causing offflavors, slime formation, and discoloration, making the meat unfit to consume (Das et al., 2019). The wide range of microflora (bacteria, yeasts and moulds), including pathogens are primarily found in the animal's digestive system and skin. The microflora in meat is influenced by several factors like pre-slaughter husbandry practices, animal age at slaughter, handling during slaughtering, evisceration, and processing, preservation methods, packaging, consumer handling, and storage (Ajaykumar and Mandal, 2019). Microorganisms colonise and proliferate on meat surfaces in stages, the first of which includes the attachment of bacterial cells (Donlan, 2002). Acinetobacter, Pseudomonas, Brochothrix, Flavobacterium, Psychrobacter, Moraxella, Campylobacter, Clostridium, Listeria, Salmonella, Staphylococcus, Micrococcus, lactic acid bacteria (LAB), and Enterobacteriaceae and also mould species such as Cladosporium, Penicillium, Mucor, Geotrichum and yeast species (Candida and Cryptococcus) are the commonest microbial genera isolated from fresh meat (Odeyemi et al., 2020). Microbial development within the $\mathrm{pH}$ range of 5.5-7.0 caused slime production, structural component degradation, off-flavors, and visual changes in meat. One of the most important factors influencing microbiological safety is water activity $\left(\mathrm{a}_{\mathrm{w}}\right)$. The word "water activity" $\left(\mathrm{a}_{\mathrm{w}}\right)$ refers to the water that helps microorganisms flourish. Pathogen development is inhibited at $\mathrm{a}_{\mathrm{w}}$ of 0.85 . Reducing water activity can prevent the growth of gram negative bacteria (that can withstand an $\mathrm{a}_{\mathrm{w}}$ of 0.94-0.97) in processed and cured meats (Addis, 2015). Sliminess, souring, and greening are the three types of spoilage in meat products. Sliminess on the surface of meat is caused by species of genus Pseudomonas, Acinetobacter, Moraxella, Alcaligenes, Streptococcus, Leuconostoc, Bacillus, Micrococcus. Lactobacillus spp. and Leuconostoc are responsible for the color change in meat products. Oxidative rancidity in meat is caused by Pseudomonas, Achromobacter spp., and yeast. Aerobic growth of moulds causes stickiness, whiskers, black spot, and white spot in meat products. Under anaerobic conditions, facultative bacteria are responsible for souring, putrefaction, and different taints. Therefore, different natural antimicrobial agents are being incorporated into the meat products to inhibit spoilage and enhance the meat preservation methods.

\section{Natural antioxidants in meat and meat products}

Antioxidants are the chemicals/substances added to fresh and processed meat and meat products to reduce lipid oxidation, prevent the formation of off-flavors, and increase colour stability. They are classified as natural or synthetic antioxidants in the meat industry. Synthetic antioxidants such as butylated hydroxytoluene (BHT) and butylated hydroxyanisole (BHA) were widely employed to delay, retard, or prevent lipid oxidation by scavenging chain-carrying peroxyl radicals or reducing the generation of free radicals. The toxicological and carcinogenic consequences of synthetic antioxidants have been established and hence, natural products were preferred over synthetic ones in the meat industry (Kumar et al., 2015). Natural antioxidants include phenolic components such as flavonoids and 
phenolic acid, vitamins, and volatile chemicals found in various fruits, plants, herbs, and spices. Polyphenolic compounds (tocopherols, flavonoids, phenolic acids) are the active components of natural antioxidants. These phenolic compounds can function as reducing agents, free radical terminators, metal chelators, or singlet oxygen quenchers (Shahidi and Ambigaipalan, 2015). Plants have been identified as a potential source of useful bioactive compounds and considered as natural antioxidants to enhance the chemical quality of meat and meat products. To limit lipid oxidation and the development of secondary breakdown products, antioxidant additives have been incorporated in meat and meat products. Ascorbic acid (vitamin C), alpha-tocopherol (vitamin E), beta-carotene (vitamin A precursor), many flavonoids, and other phenolic components are all linked to the total antioxidant capacity of extracts of various plant materials such as culinary herbs, spices, vegetables, fruits, and oilseed products (Aminzare et al., 2016). Plant extracts are derived from plant materials utilising a variety of solvents and extraction techniques. These extracts are high in phenolic acids and can be used instead of synthetic antioxidants. Diphenyl-1-picrylhydrazyl $(\mathrm{DPPH})$, superoxide anion scavenging assay, phosphomolybdate assay (total antioxidant capacity), hydrogen radical scavenging assay, hydrogen peroxide scavenging activity, 2,2azinobis-3-ethylbenzthiazoline-6-sulphonic acid (ABTS) radical scavenging activity, and reducing power can all be used to determine the antioxidant properties of plant extracts. A large number of plant sources have been examined as natural antioxidants in meat. These antioxidants were harvested from leaves, roots, stems, fruits, seeds, and bark, among other plant components (Shah et al., 2014).

\section{Natural antimicrobials in meat and meat products}

Antimicrobials are different chemicals that either kill or slow the growth of microbes. They are directly added into the products or coated on the surface or incorporated into the packaging material to inhibit the microbial growth in meat and meat products. Essential oils derived from plants (e.g., basil, thyme, oregano, cinnamon, clove, and rosemary), enzymes derived from animals (e.g., lysozyme, lactoferrin), bacteriocins derived from bacteria (nisin, natamycin), organic acids (e.g., sorbic, propionic, citric acid), are the most common natural antimicrobial compounds used in meat products. Flavonoids, thiosulfinates, glucosinolates, phenolics, organic acids, and saponins are antimicrobial components of plants. However, phenols, which comprise terpenes, isoflavonoids, aliphatic alcohols, aldehydes, ketones, and acids are the major components having antibacterial activity. Plant essential oils' antimicrobial activity is attributed to their chemical composition, specifically the presence of hydrophilic functional groups such as hydroxyl groups in phenolic components and/or lipophilicity in certain essential oil components. Gram-positive bacteria are more resistant to the phenolic components of the plant essential oils' than Gram-negative bacteria (Lucera et al., 2012). Essential oils can be regarded as healthy additives to use in meat and meat products because they are plant extracts with antibacterial, antioxidative, and flavorful qualities. If essential oils are used in meat products, they can help to lower the risk of foodborne illness and slow the oxidation of lipids in the meat (Arshad and Batool, 2017). Biopreservation of meat products using bacteriocins extends the inhibitory activity spectrum to Gram-negative bacteria and enhances the safety and quality of meat products (Amin, 2012).

\section{Use of natural antioxidants and natural antimicrobials for meat, meat products}

Natural plants are a major subject matter to focus to find novel sources of natural antioxidants and antimicrobials, and their application in meat products is becoming increasingly vital. Realini et al. (2014) observed that $0.15 \% \mathrm{w} / \mathrm{w}$ of acerola fruit extract increased 
the color stability and decreased the rancid flavours, and extended the shelf-life of salted beef patties. Active packaging material coated with citrus extract was found to be effective in limiting lipid oxidation and an increase in the tenderness of the cooked turkey meat was observed in the studies (Contini et al., 2014). Andrés et al. (2017) showed that in vitro antioxidant activity was highest in grape and olive pomace aqueous extracts, which substantially reduced discolouration as well as lipid and protein oxidation and retained the microbiological quality in raw lamb patties during chilling. Cuong and Chin (2018) found that the addition of $0.25 \%$ annatto (Bixa orellana $L$.) seed powder extended the shelflife of pork patties. Annatto seed powder possessed antioxidant properties, had less lipid degradation, and increased the redness of pork patties due to the presence of bixin and norbixin pigments. Krkic et al. (2013) observed a better odor and flavor profile with less oxidative changes in dry fermented sausages incorporated with essential oils of oregano (Origanum vulgare) and coated with chitosan after a long time of storage. Lorenzo and Pateiro (2013) compared the physico-chemical effect and oxidative stability of the natural antioxidants, such as green tea, chestnut, and grape seed extracts with that of synthetic antioxidant (BHT) in pig liver pate. The studies revealed lower TBARS values and reduced lipid oxidation during the storage period. Similar results were obtained by Doolaege et al. (2012) in pig liver pate with the addition of rosemary extract. Almeidan et al. (2015) considered jabuticaba peel extract as a promising natural additive in Bologna-type sausages. Jabuticaba peel contains phenolic compounds such as anthocyanins and flavonols, which are capable of complexing free radicals and inhibiting the oxidative reactions caused by free radicals, delaying or preventing lipid oxidation reactions, and extending the shelf life of the sausages. The effect of different phytochemicals on various quality changes of meat and meat products is summarized and presented in Table 1.
Ding et al. (2015) studied the effects of ground litchi flower on lipid peroxidation and protein degradation of pork meatballs during freezing. The studies revealed superior textural character, color profile, and water-holding ability of meatballs due to increased myofibrillar protein levels. The main phenolic acid and flavonoid of the litchi flower were gentisic acid and epicatechin, respectively. Thus, the polyphenol-rich litchi flowers could be a useful natural antioxidant for reducing lipid and protein oxidation in frozen cooked meats. Oleynikov (2020) reported that the antioxidant of oregano extract enhanced the shelf life and quality of ground beef and also showed positive results on color stability indexes. Skandamis et al. (2002) studied the effect of oregano essential oil on the behaviour of Salmonella Typhimurium in beef fillets stored under aerobic, vacuum packaging, modified atmosphere packaging environment. They observed a reduction in microbes in meat, predominantly, Lactic acid bacteria and Salmonella Typhimurium in both the packaging methods.

Thus, vacuum packaging or modified atmosphere packaging combined with oregano essential oil may be a more efficient option for controlling meat deterioration and increasing safety, as these collective hurdles may have a synergistic impact. Munekata et al. (2015) conducted studies on the effect of peanut skin extract in chicken meat patties and sheep patties to evaluate the antioxidant activity and physicochemical properties. Phenolic compounds such as proanthocyanidins, flavanols, stilbenes, and polymers are significant antioxidant compounds found in peanut skin. The application of peanut skin extract to cooked chicken patties effectively reduced lipid oxidation and retained redness, despite a modest darkening of the samples. Zhang et al. (2013) assessed the effect of antioxidant activity of sage (Salvia officinalis) in Chinese-style sausage during refrigeration. The results showed lower TBARS values and protein carbonyls indicating retarded lipid and protein oxidation. Therefore, sage has been shown to improve the oxidative 
Table 1. Effect of different phytochemicals on safety and quality of meat and meat products

\begin{tabular}{|c|c|c|c|c|}
\hline $\begin{array}{c}\text { Meat and } \\
\text { meat products }\end{array}$ & Phytochemicals & $\begin{array}{l}\text { Level } \\
\text { used }\end{array}$ & $\begin{array}{l}\text { Impact on meat and } \\
\text { meat products }\end{array}$ & References \\
\hline $\begin{array}{l}\text { Chicken } \\
\text { nuggets }\end{array}$ & $\begin{array}{l}\text { Dragon fruit peel } \\
\text { powder }\end{array}$ & $3 \%$ & $\begin{array}{l}\checkmark \text { Improved emulsion stability and } \\
\text { cooking yield } \\
\checkmark \text { Decreased hardness, gumminess } \\
\text { and chewiness } \\
\checkmark \text { Improved the redmess values } \\
\checkmark \text { Decreased lipid peroxidation, } \\
\quad \text { odour scores and microbial load }\end{array}$ & $\begin{array}{l}\text { Madane } \\
\text { et al. (2020) }\end{array}$ \\
\hline $\begin{array}{l}\text { Chicken } \\
\text { nuggets }\end{array}$ & $\begin{array}{l}\text { Drumstick flower } \\
\text { extract }\end{array}$ & $2 \%$ & $\begin{array}{l}\checkmark \text { Reduced the redness, hardness, } \\
\text { gumminess and chewiness } \\
\checkmark \text { Improved the oxidative stability } \\
\text { and odour scores } \\
\checkmark \text { No significant changes in sensory } \\
\text { attributes }\end{array}$ & $\begin{array}{l}\text { Madane } \\
\text { et al. (2019) }\end{array}$ \\
\hline $\begin{array}{l}\text { Chicken } \\
\text { burger }\end{array}$ & Pomegranate peel & $\begin{array}{l}20 \% \\
30 \%\end{array}$ & $\begin{array}{l}\checkmark \text { Decreased the acid, peroxide and TBA } \\
\text { values of their lipids } \\
\checkmark \quad \text { Retarded the growth of total molds and } \\
\text { yeasts, total bacterial, psychrophilic } \\
\text { bacteria and spore-forming } \\
\checkmark \quad \text { Improved the appearance, odor, } \\
\text { texture, and taste }\end{array}$ & Aly (2019) \\
\hline $\begin{array}{l}\text { Sheep meat } \\
\text { nuggets }\end{array}$ & $\begin{array}{l}\text { Litchi pericarp } \\
\text { extract }\end{array}$ & $1.5 \%$ & $\begin{array}{l}\checkmark \text { Increased the phenolic contentü } \\
\text { Inhibited the lipid peroxidation } \\
\checkmark \text { Improved the product quality, } \\
\text { stability and safety }\end{array}$ & $\begin{array}{l}\text { Das } \\
\text { et al. (2016) }\end{array}$ \\
\hline Frankfurters & $\begin{array}{l}\text { Cacao pod husk } \\
\text { flour }\end{array}$ & $1.5 \%$ & $\begin{array}{l}\text { Higher water content, hardness } \\
\text { and adhesiveness } \\
\checkmark \text { Decreased springiness }\end{array}$ & $\begin{array}{l}\text { Delgado- } \\
\text { Ospina } \\
\text { et al. }(2021) \\
\end{array}$ \\
\hline Pork nuggets & $\begin{array}{l}\text { Kordoi fruit juice } \\
\text { and bamboo shoot } \\
\text { extract }\end{array}$ & $\begin{array}{l}4 \% \\
6 \%\end{array}$ & $\begin{array}{l}\checkmark \text { Retarded quality deterioration } \\
\text { and lipid peroxidation } \\
\checkmark \text { Improved the microbiological } \\
\text { characteristics } \\
\checkmark \text { Improved flavor } \\
\end{array}$ & $\begin{array}{l}\text { Thomas } \\
\text { et al. (2016) }\end{array}$ \\
\hline $\begin{array}{l}\text { Buffalo veal } \\
\text { slices }\end{array}$ & Grape seed extract & $0.2 \%$ & $\begin{array}{l}\checkmark \text { Decreased microbial count } \\
\checkmark \text { Improved sensory characteristics } \\
\checkmark \text { Better antioxidant activity }\end{array}$ & $\begin{array}{l}\text { Singh } \\
\text { et al. (2018) }\end{array}$ \\
\hline Pork nuggets & $\begin{array}{l}\text { Black cumin and } \\
\text { arjuna fruit extract }\end{array}$ & $\begin{array}{l}1.5 \% \\
1 \%\end{array}$ & $\begin{array}{l}\checkmark \text { Improved the flavour and overall } \\
\text { acceptability scores } \\
\checkmark \text { Lowered mean total aerobic plate } \\
\text { count } \\
\checkmark \text { Inhibited lipid oxidation and } \\
\text { microbial growth }\end{array}$ & $\begin{array}{l}\text { Chauhan } \\
\text { et al. (2018) }\end{array}$ \\
\hline
\end{tabular}


Cont. Table 1.

\begin{tabular}{|c|c|c|c|c|}
\hline $\begin{array}{c}\text { Meat and } \\
\text { meat products }\end{array}$ & Phytochemicals & $\begin{array}{l}\text { Level } \\
\text { used }\end{array}$ & $\begin{array}{l}\text { Impact on meat and } \\
\text { meat products }\end{array}$ & References \\
\hline $\begin{array}{l}\text { Goat meat } \\
\text { nuggets }\end{array}$ & $\begin{array}{l}\text { Litchi pericarp } \\
\text { powder }\end{array}$ & $2 \%$ & $\begin{array}{l}\checkmark \text { Improved redness value and } \\
\text { colour } \\
\checkmark \text { Softened the texture } \\
\checkmark \text { Improved the products } \\
\text { physicochemical quality } \\
\checkmark \text { Enriched the product with } \\
\quad \text { dietary fibre, phenolic content } \\
\checkmark \text { Resistant to lipid oxidation }\end{array}$ & $\begin{array}{l}\text { Verma } \\
\text { et al. }(2020)\end{array}$ \\
\hline $\begin{array}{l}\text { Sheep meat } \\
\text { nuggets }\end{array}$ & $\begin{array}{l}\text { Litchi pericarp } \\
\text { extract }\end{array}$ & $1.5 \%$ & $\begin{array}{l}\checkmark \text { Increased phenolic content } \\
\checkmark \text { Inhibited lipid peroxidation } \\
\checkmark \text { Improved product quality and } \\
\quad \text { safety }\end{array}$ & $\begin{array}{l}\text { Das } \\
\text { et al. (2016) }\end{array}$ \\
\hline $\begin{array}{l}\text { Raw ground } \\
\text { pork }\end{array}$ & $\begin{array}{l}\text { Terminalia arjuna } \\
\text { fruit extract }\end{array}$ & $1 \%$ & $\begin{array}{l}\checkmark \text { Improved the oxidative } \\
\text { stability } \\
\checkmark \text { Improved the colour and } \\
\text { odour scores } \\
\checkmark \text { Lowered rancid odour } \\
\text { development }\end{array}$ & $\begin{array}{l}\text { Chauhan } \\
\text { et al. (2019) }\end{array}$ \\
\hline $\begin{array}{l}\text { Chicken } \\
\text { patties }\end{array}$ & $\begin{array}{l}\text { Plum peel and pulp } \\
\text { microparticles }\end{array}$ & $2 \%$ & $\begin{array}{l}\checkmark \text { Improved antioxidant activity } \\
\checkmark \text { Increased redness and } \\
\text { springiness } \\
\checkmark \text { Improved textural parameters }\end{array}$ & $\begin{array}{l}\text { Basanta } \\
\text { et al. (2018) }\end{array}$ \\
\hline $\begin{array}{l}\text { Cooked pork } \\
\text { patties }\end{array}$ & $\begin{array}{l}\text { Light and dark } \\
\text { roasted coffee }\end{array}$ & $1 \mathrm{~g} / \mathrm{kg}$ & $\checkmark$ Inhibited lipid oxidation & $\begin{array}{l}\text { Jully } \\
\text { et al. (2016) }\end{array}$ \\
\hline Pork patties & $\begin{array}{l}\text { Ethanol extract of } \\
\text { tomato powder }\end{array}$ & $1 \%$ & $\begin{array}{l}\checkmark \text { Increased the redness value } \\
\checkmark \text { Lowered bacterial counts } \\
\checkmark \text { Inhibited lipid oxidation }\end{array}$ & $\begin{array}{l}\text { Kim and } \\
\text { Chin (2017) }\end{array}$ \\
\hline $\begin{array}{l}\text { Chicken } \\
\text { mortadella }\end{array}$ & Moringa seed flour & $3 \%$ & $\begin{array}{l}\checkmark \text { Increased lipid stability } \\
\checkmark \text { Smoothened the texture } \\
\checkmark \text { Increased the lightness }\end{array}$ & $\begin{array}{l}\text { Auriema } \\
\text { et al. (2019) }\end{array}$ \\
\hline Chicken fillets & $\begin{array}{l}\text { Nanoemulsions of } \\
\text { curcumin with } \\
\text { cinnamon essential } \\
\text { oil, garlic essential } \\
\text { oil and sunflower oil }\end{array}$ & $\begin{array}{l}40 \mathrm{~nm}, \\
9 \mathrm{~nm}, \\
130 \mathrm{~nm}\end{array}$ & $\begin{array}{l}\checkmark \text { Retarded microbial spoilage } \\
\checkmark \text { Best water holding capacity } \\
\text { and texture } \\
\checkmark \text { Higher sensory scores }\end{array}$ & $\begin{array}{l}\text { Abdou } \\
\text { et al. (2018) }\end{array}$ \\
\hline $\begin{array}{l}\text { Chicken } \\
\text { sausage }\end{array}$ & Sugarcane fibre & $3 \%$ & $\begin{array}{l}\checkmark \text { Increased the cooking yield } \\
\checkmark \text { Decreased lipid oxidation } \\
\checkmark \text { Increased the hardness and } \\
\text { springiness }\end{array}$ & $\begin{array}{l}\text { Fang } \\
\text { et al. (2019) }\end{array}$ \\
\hline $\begin{array}{l}\text { Sheep } \\
\text { sausages }\end{array}$ & Oregano extract & $\begin{array}{l}6630.98 \\
\text { and }\end{array}$ & $\begin{array}{l}3 \checkmark \text { Improved lipid and protein } \\
\text { stability }\end{array}$ & $\begin{array}{l}\text { Fernandes } \\
\text { et al. (2018) }\end{array}$ \\
\hline
\end{tabular}


Cont. Table 1.

\begin{tabular}{|c|c|c|c|c|}
\hline $\begin{array}{c}\text { Meat and } \\
\text { meat products }\end{array}$ & Phytochemicals & $\begin{array}{l}\text { Level } \\
\text { used }\end{array}$ & $\begin{array}{l}\text { Impact on meat and } \\
\text { meat products }\end{array}$ & References \\
\hline & & $\begin{array}{l}8038.20 \\
\mathrm{mg} / \mathrm{kg}\end{array}$ & $\begin{array}{l}\checkmark \text { Better antioxidant potentiality } \\
\checkmark \text { Higher sensory scores }\end{array}$ & \\
\hline $\begin{array}{l}\text { Cooked } \\
\text { sausage }\end{array}$ & Lotus rhizome & $>1 \%$ & $\begin{array}{l}\checkmark \text { Increased darker and red color } \\
\checkmark \text { Improved emulsion stability } \\
\text { and viscosity } \\
\checkmark \text { Reduced cooking loss } \\
\checkmark \text { Decreased color and juiciness } \\
\text { scores } \\
\checkmark \text { Improved springiness and } \\
\quad \text { chewiness }\end{array}$ & $\begin{array}{l}\text { Ham } \\
\text { et al. (2017) }\end{array}$ \\
\hline $\begin{array}{l}\text { Chicken meat } \\
\text { nuggets }\end{array}$ & $\begin{array}{l}\text { Gooseberry pulp } \\
\text { powder and seed } \\
\text { coat powder }\end{array}$ & $\begin{array}{l}0.5 \% \\
1 \%\end{array}$ & $\begin{array}{ll}\checkmark \text { Decreased coliform count } \\
\checkmark \text { Increased moisture content } \\
\checkmark \text { Improved sensory attributes }\end{array}$ & $\begin{array}{l}\text { Mayank } \\
\text { et al. (2019) }\end{array}$ \\
\hline $\begin{array}{l}\text { Carabeef } \\
\text { nuggets }\end{array}$ & $\begin{array}{l}\text { Pomegranate rind } \\
\text { powder }\end{array}$ & $4 \%$ & $\begin{array}{l}\text { Increased crude fiber and } \\
\text { antioxidant activity } \\
\checkmark \text { Acceptable sensory score }\end{array}$ & $\begin{array}{l}\text { Habib } \\
\text { et al. (2018) }\end{array}$ \\
\hline
\end{tabular}

stability of Chinese-style sausage while having no adverse effects on the sensory attributes.

Bostan and Isin Mohan (2011) investigated the microbiological quality and shelf-life of sausage treated with chitosan. The results indicated that in terms of slowing down the growth of aerobic mesophilic bacteria and psychrotrophic bacteria, chitosan concentrations of $0.25 \%$ were sufficient, whereas larger concentrations $(0.5 \%$ and $1.0 \%)$ were required for lactic acid bacteria and yeast-mold, respectively. Therefore, chitosan can be utilised as an alternative natural preservative in sausages, according to the findings. Studies by Mastromatteo et al. (2011) showed that lemon alkott, a citrus extract, and thymol, a spice extract, have the greatest sensorial scores and the modified atmosphere packaging (MAP) methods in pork back fat sausages had an antibacterial effect, and low carbon dioxide levels resulted in less colour fluctuation during storage. Furthermore, both thymol alone and in combination with MAP improved the shelf life of reduced pig back-fat content sausages. Souza et al. (2009) evaluated the combined effect of essential oil of oregano and acetic acid against Staphylococcus aureus in meat pieces. The findings of this study demonstrated the effect of applying $O$. vulgare essential oil and acetic acid at sub-inhibitory concentrations. The effective combination of essential oils and organic acids could provide a more natural and appealing alternative to the meat industry, implying an extra barrier to prevent infections and spoilage microorganisms from growing and surviving in foods. Similar works by Busatta et al. (2007) reported that satisfactory performance was accomplished with a low concentration of oregano essential oil as an antibacterial agent against numerous microorganisms, resulting in a longer product shelf-life with just a little change in the original taste criteria. Min et al. (2010) reported that antimicrobial gelatine films such as Nisaplin film and Guardian films effectively inhibited the growth of Listeria monocytogenes in turkey bologna during the storage period. A schematic diagram of effect of different phytochemicals on the safety and quality of meat and meat products is presented in Fig. 1. 


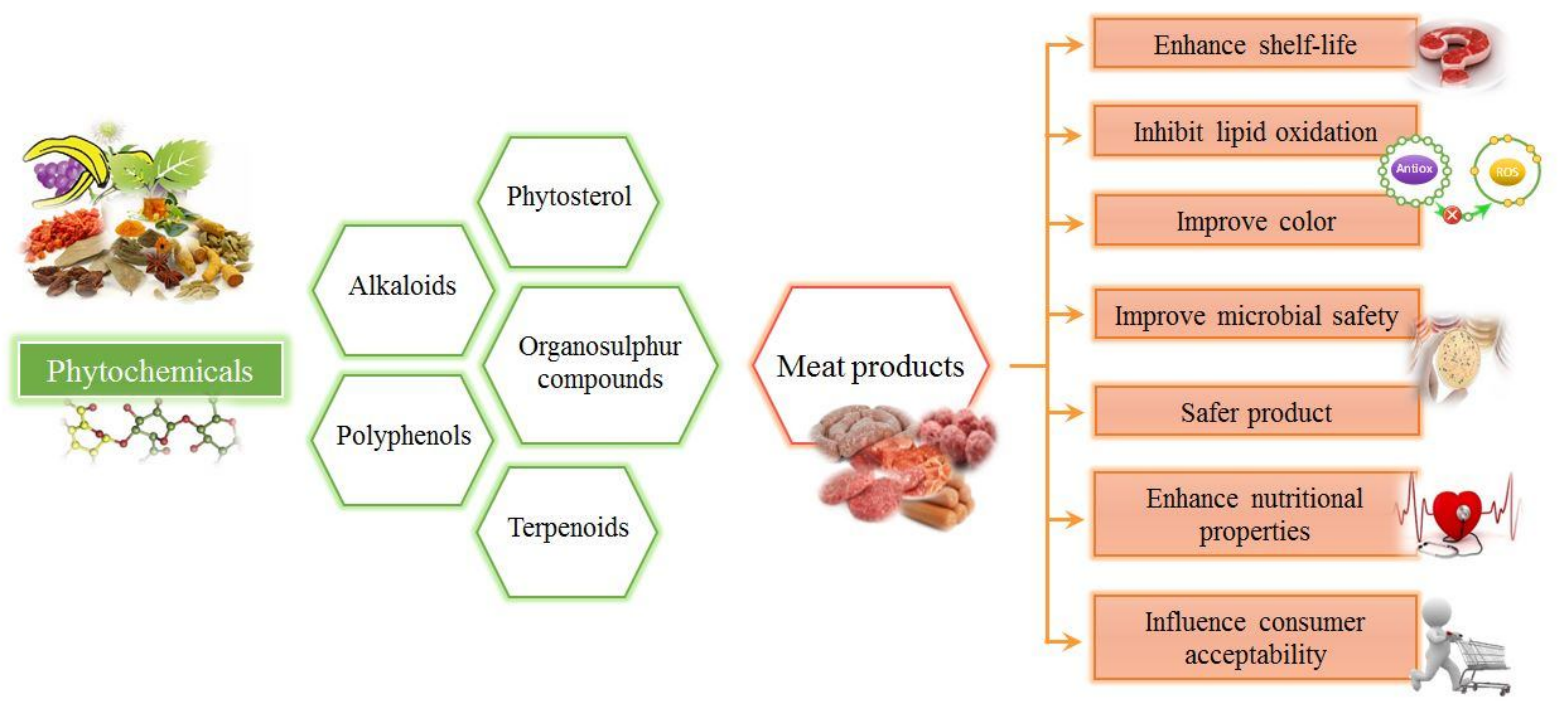

Fig. 1. Schematic diagram on effect of different phytochemicals on safety and quality of meat and meat products

\section{Conclusion}

Oxidation and microbial spoilage are the major problems reducing the shelf life of meat and meat products. To limit these reactions, synthetic chemicals were utilised. However, in response to the rising consumer demand for natural bioactive molecules to replace synthetic chemicals, numerous studies have been conducted to identify new and natural sources of antioxidant and antimicrobial chemicals. Various chemical compounds originating from plants that can be employed as natural antioxidants and antimicrobials in meat and meat products have been isolated from various plant components such as leaves, stems, roots, fruits, bark, and seeds. Plants rich in polyphenols that are employed as food preservatives are the best alternative to their synthetic counterparts. The amount of polyphenolic-rich plants necessary in the meat system for effective antibacterial and antioxidant activities is frequently too large to be organoleptically acceptable. To improve the antioxidant qualities of meat and meat products, future research should focus on novel technologies such as high-pressure processing, pulsed electric fields, and ultrasound mixed with natural antioxidants. Another new trend is the use of antimicrobial in edible films and coatings in combination with various packaging techniques to extend the shelf life of meat and meat products. Meat and meat products can be sprayed with antimicrobials, or meat can be dipped in them. Because all-natural chemicals have the potential to be fully innocuous to human health, there is a growing market for natural antimicrobials to be employed as preservatives. Thus, investigations on analysing synergistic effects and optimization using plantbased natural preservatives are needed to increase our understanding of how to make meat products with extended shelf life and no synthetic preservatives while maintaining senility.

Conflict of interest: Authors have no conflict of interest in this study.

Author's contribution: OB, SP, AKD: Collected informations, analyzed, interpreted the references and wrote the first draft; JML, PK and AKD: Revised the manuscript.

\section{ACKNOWLEDGMENTS}

The authors are grateful to the Editorial Board of IJAH for giving them the opportunity to write a review article for their special issue. 


\section{REFERENCES}

Abdou ES, Galhoum GF and Mohamed EN, 2018. Curcumin loaded nanoemulsions/pectin coatings for refrigerated chicken fillets. Food Hydrocoll, 83: 445-453, doi: 10.1016/j.foodhyd.2018.05.026

Addis M, 2015. Major causes of meat spoilage and preservation techniques: A review. Food Sci Qual Manag, 41: 2224-6088

Ajaykumar VJ and Mandal PK, 2019. Chapter 18Modern concept and detection of spoilage in meat and meat products. In: Meat Quality Analysis: Advanced Evaluation Methods, Techniques, and Technologies. pp 335-349, doi: 10.1016/B9780-12-819233-7.00018-5

Almeidan PL, de Lima SN, Costa LL, de Oliveira CC, Damasceno KA et al., 2015. Effect of jabuticaba peel extract on lipid oxidation, microbial stability and sensory properties of Bologna-type sausages during refrigerated storage. Meat Sci, 110: 9-14, doi: 10.1016/j.meatsci.2015.06.012

Aly AA, 2019. Utilization of pomegranate peels to increase the shelf life of chicken burger during cold storage. Egypt J Food Sci, 47(1): 1-10, doi: 10.21608/ejfs.2019.11319.1002

Amaral AB, da Silva MVD and da Silva Lannes SC, 2018. Lipid oxidation in meat: mechanisms and protective factors - A review. Food Sci Technol, 38(Suppl 1): 1-15, doi: 10.1590/fst.32518

Amin RA, 2012. Effect of bio preservation as a modern technology on quality aspects and microbial safety of minced beef. Glob J Biotechnol Biochem, 7(2): 38-49

Aminzare M, Hashemi M, Hassanzad Azar H and Hejazi J, 2016. The use of herbal extracts and essential oils as a potential antimicrobial in meat and meat products; A review. J Hum Environ Health Promot, 1(2): 63-74, doi: 10.29252/jhehp.1.2.63

Andrés AI, Petrón MJ, Adámez JD, López M and Timón ML, 2017. Food by-products as potential antioxidant and antimicrobial additives in chill stored raw lamb patties. Meat Sci, 129: 62-70, doi: 10.1016/j.meatsci.2017.02.013

Arshad MS and Batool SA, 2017. Natural Antimicrobials, their Sources and Food Safety. In: Food Additives. pp 87-100, doi: 10.5772/ intechopen.70197

Auriema BE, Dinalli VP, Kato T, Yamaguchi MM, Marchi DF et al., 2019. Physical and chemical properties of chicken mortadella formulated with Moringa oleifera Lam. seed flour. Food Sci Technol, 39(Supll 2): 504-509, doi: 10.1590/ fst. 25018
Aziz M and Karboune S, 2018. Natural antimicrobial/ antioxidant agents in meat and poultry products as well as fruits and vegetables: A review. Crit Rev Food Sci Nutr, 58(3): 486-511, doi: 10.1080/ 10408398.2016.1194256

Basanta MF, Rizzo SA, Szerman N, Vaudagna SR, Descalzo AM et al., 2018. Plum (Prunus salicina) peel and pulp microparticles as natural antioxidant additives in breast chicken patties. Food Res Int, 106: 1086-1094, doi: 10.1016/j.foodres. 2017.12.011

Bostan K and Isin Mahan F, 2011. Microbiological quality and shelf-life of sausage treated with chitosan. Istanbul Univ Vet Fak Derg, 37(2): 117126, doi: 10.16988/IUVFD.72072

Busatta C, Mossi AJ, Rodrigues MRA, Cansian RL and De Oliveira JV, 2007. Evaluation of Origanum vulgare essential oil as antimicrobial agent in sausage. Brazilian J Microbiol, 38(4): 610-616, doi: $10.1590 / \mathrm{S} 1517-83822007000400006$

Chaijan M, 2008. Review: Lipid and myoglobin oxidations in muscle foods. Songklanakarin J Sci Technol, 30(1): 47-53

Chauhan P, Das AK, Das A, Bhattacharya D and Nanda PK, 2018. Effect of black cumin and arjuna fruit extract on lipid oxidation in pork nuggets during refrigerated storage. J Meat Sci, 13(1): 73-80, doi: 10.5958/2581-6616.2018.00011.7

Chauhan P, Pradhan SR, Das A, Nanda PK, Bandyopadhyay S et al., 2019. Inhibition of lipid and protein oxidation in raw ground pork by Terminalia arjuna fruit extract during refrigerated storage. Asian-Australa J Anim Sci, 32(2): 265273, doi: 10.5713/ajas.17.0882

Contini C, Álvarez R, O'Sullivan M, Dowling DP, Gargan SÓ et al., 2014. Effect of an active packaging with citrus extract on lipid oxidation and sensory quality of cooked turkey meat. Meat Sci, 96(3): 1171-1176, doi: 10.1016/ j.meatsci.2013.11.007

Cuong VT and Chin KB, 2018. Evaluation of Cudrania tricuspidata leaves on antioxidant activities and physicochemical properties of pork patties. Korean J food Sci Anim Resour, 38(5): 889-900, doi: 10.5851/kosfa.2018.e22

Das AK, Nanda PK, Bandyopadhyay S, Banerjee R, Biswas S et al., 2020. Application of nanoemulsionbased approaches for improving the quality and safety of muscle foods: A comprehensive review. Compr Rev Food Sci Food Saf, 19(5): 2677-2700, doi: 10.1111/1541-4337.12604 
Das AK, Nanda PK, Das A and Biswas S, 2019. Hazards and safety issues of meat and meat products. In: Food Safety and Human Health. Elsevier Academic Press, pp 145-168, doi: 10.1016/B978-0-12816333-7.00006-0

Das AK, Rajkumar V, Nanda PK, Chauhan P, Pradhan SR et al., 2016. Antioxidant efficacy of litchi (Litchi chinensis Sonn.) pericarp extract in sheep meat nuggets. Antioxidants, 5(2): 16, doi: 10.3390/ antiox 5020016

Dave D and Ghaly AE, 2011. Meat spoilage mechanisms and preservation techniques: A critical review. Am J Agric Biol Sci, 6(4): 486510, doi: 10.3844/ajabssp.2011.486.510

Delgado-Ospina J, Martuscelli M, Grande-Tovar CD, Lucas-González R, Molina-Hernandez JB et al., 2021. Cacao pod husk flour as an ingredient for reformulating frankfurters: effects on quality properties. Foods, 10(6):1243, doi: 10.3390/ foods 10061243

Ding Y, Wang SY, Yang DJ, Chang MH and Chen YC, 2015. Alleviative effects of litchi (Litchi chinensis Sonn.) flower on lipid peroxidation and protein degradation in emulsified pork meatballs. J Food Drug Anal, 23(3): 501-508, doi: 10.1016/ j.jfda.2015.02.004

Domínguez R, Pateiro M, Gagaoua M, Barba FJ, Zhang $\mathrm{W}$ et al., 2019. A comprehensive review on lipid oxidation in meat and meat products. Antioxidants (Basel), 8(10): 429, doi: 10.3390/antiox 8100429

Donlan RM, 2002. Biofilms: microbial life on surfaces. Emerg Infect Dis, 8(9): 881-890, doi: 10.3201/ eid0809.020063

Doolaege EHA, Vossen E, Raes K, De Meulenaer B, Verhé R et al., 2012. Effect of rosemary extract dose on lipid oxidation, colour stability and antioxidant concentrations, in reduced nitrite liver pâtés. Meat Sci, 90(4): 925-931, doi: 10.1016/ j.meatsci.2011.11.034

Fang Z, Lin P, Ha M and Warner RD, 2019. Effects of incorporation of sugarcane fibre on the physicochemical and sensory properties of chicken sausage. Int J Food Sci Technol, 54(4): 1036-1044, doi: 10.1111/ijfs.13894

Fernandes RPP, Trindade MA, Lorenzo JM and de Melo MP, 2018. Assessment of the stability of sheep sausages with the addition of different concentrations of Origanum vulgare extract during storage. Meat Sci, 137: 244-257, doi: 10.1016/ j.meatsci.2017.11.018

Habib H, Siddiqi RA, Dar AH, Dar MA, Gul K et al., 2018. Quality characteristics of carabeef nuggets as affected by pomegranate rind powder. J Food Meas Charact, 12(3): 2164-2173, doi: 10.1007/ s11694-018-9832-2

Ham YK, Hwang KE, Song DH, Kim YJ, Shin DJ et al., 2017. Lotus (Nelumbo nucifera) rhizome as an antioxidant dietary fiber in cooked sausage: effects on physicochemical and sensory characteristics. Korean J Food Sci Anim Resour, 37(2): 219-227, doi: 10.5851/kosfa.2017.37.2.219

Huang X and Ahn DU, 2019. Lipid oxidation and its implications to meat quality and human health. Food Sci Biotechnol, 28(5): 1275-1285, doi: 10.1007/s10068-019-00631-7

Jully KMM, Toto CS and Were L, 2016. Antioxidant effect of spent, ground, and lyophilized brew from roasted coffee in frozen cooked pork patties. LWT - Food Sci Technol, 66: 244-251, doi: 10.1016/ j.lwt.2015.10.046

Kim HS and Chin KB, 2017. Evaluation of antioxidative activity of various levels of ethanol extracted tomato powder and application to pork patties. Korean J Food Sci Anim Resour, 37(2): 242-253, doi: 10.5851/kosfa.2017.37.2.242

Krkić N, Šojić B, Lazić V, Petroviæ L, Mandić A et al., 2013. Lipid oxidative changes in chitosanoregano coated traditional dry fermented sausage Petrovská klobása. Meat Sci, 93(3): 767-770, doi: 10.1016/j.meatsci.2012.11.043

Kumar Y, Yadav DN, Ahmad T and Narsaiah K, 2015. Recent trends in the use of natural antioxidants for meat and meat products. Compr Rev Food Sci Food Saf, 14(6): 796-812, doi: 10.1111/15414337.12156

Lorenzo JM and Pateiro M, 2013. Influence of type of muscles on nutritional value of foal meat. Meat Sci, 93(3): 630-638, doi: 10.1016/ j.meatsci.2012.11.007

Lucera A, Costa C, Conte A and Del Nobile MA, 2012. Food applications of natural antimicrobial compounds. Front Microbiol, 3(AUG), doi: 10.3389/fmicb.2012.00287

Madane P, Das AK, Nanda PK, Bandyopadhyay S, Jagtap P et al., 2020. Dragon fruit (Hylocereus undatus) peel as antioxidant dietary fibre on quality and lipid oxidation of chicken nuggets. J Food Sci Technol, 57(4): 1449-1461, doi: 10.1007/s13197-019-04180-z

Madane P, Das AK, Pateiro M, Nanda PK, Bandyopadhyay S et al., 2019. Drumstick (Moringa oleifera) flower as an antioxidant dietary fibre in chicken meat nuggets. Foods, 8(8): 307, doi: 10.3390/foods 8080307 
Mastromatteo M, Incoronato AL, Conte A and Del Nobile MA, 2011. Shelf life of reduced pork backfat content sausages as affected by antimicrobial compounds and modified atmosphere packaging. Int J Food Microbiol, 150(1): 1-7, doi: 10.1016/ j.ijfoodmicro.2011.07.009

Mayank G, Prajapati B, Solanki B, Shishir N and Shendurse A. 2019. Shelf life evaluation of chicken meat nuggets incorporated with gooseberry (pulp and seed coat) powder as natural preservatives at refrigerated storage $\left(4 \pm 1^{\circ} \mathrm{C}\right)$. Int $\mathrm{J}$ Livest Res, 9(5): 53-63, doi: 10.5455/ ijlr.20181128065146

Min BJ, Han IY and Dawson PL, 2010. Antimicrobial gelatin films reduce Listeria monocytogenes on turkey bologna. Poult Sci, 89(6): 1307-1314, doi: 10.3382/ps.2009-00451

Munekata PES, Calomeni AV, Rodrigues CEC, FávaroTrindade CS, Alencar SM et al., 2015. Peanut skin extract reduces lipid oxidation in cooked chicken patties. Poult Sci, 94(3): 442-446, doi: 10.3382/ ps/pev005

Odeyemi OA, Alegbeleye OO, Strateva M and Stratev D, 2020. Understanding spoilage microbial community and spoilage mechanisms in foods of animal origin. Compr Rev Food Sci Food Saf, 19(2): 311-331, doi: 10.1111/1541-4337.12526

Oleynikov VV, 2020. Antioxidant and antimicrobial properties of oregano extract (Origani vulgaris herba L.). Foods Raw Mater, 8(1): 84-90, doi: 10.21603/2308-4057-2020-1-84-90

Realini CE, Guàrdia MD, Díaz I, García-Regueiro JA and Arnau J, 2014. Effects of acerola fruit extract on sensory and shelf-life of salted beef patties from grinds differing in fatty acid composition. Meat Sci, 99: 18-24, doi: 10.1016/j.meatsci.2014.08.008

Ribeiro JS, Santos MJMC, Silva LKR, Pereira LCL, Santos IA et al., 2019. Natural antioxidants used in meat products: A brief review. Meat Sci, 148: 181-188, doi: 10.1016/j.meatsci.2018.10.016

Shah MA, Bosco SJD and Mir SA, 2014. Plant extracts as natural antioxidants in meat and meat products. Meat Sci, 98(1): 21-33, doi: 10.1016/ j.meatsci.2014.03.020

Shahidi F and Ambigaipalan P, 2015. Phenolics and polyphenolics in foods, beverages and spices: antioxidant activity and health effects - A review. J Funct Foods, 18: 820-897, doi: 10.1016/ j.jff.2015.06.018

Singh PK, Ahlawat SS, Sharma DP, Jairath G and Pathera A, 2018. Effect of grape seed extract on storage stability of buffalo veal slices at refrigeration temperature $\left(4 \pm 1^{\circ} \mathrm{C}\right)$. J Food Saf, 38(5): 12500, doi: 10.1111/jfs. 12500

Skandamis P, Tsigarida E and Nychas GJE, 2002. The effect of oregano essential oil on survival/death of Salmonella typhimurium in meat stored at $5^{\circ} \mathrm{C}$ under aerobic, VP/MAP conditions. Food Microbiol, 19(1): 97-103, doi: 10.1006/fmic.2001.0447

Souza EL, de Barros JC, da Conceição ML, Neto NJG and da Costa ACV, 2009. Combined application of Origanum vulgare L. essential oil and acetic acid for controlling the growth of Staphylococcus aureus in foods. Braz J Microbiol, 40(2): 387-393, doi: 10.1590/S1517-838220090002000032

Thomas R, Jebin N, Saha R and Sarma DK, 2016. Antioxidant and antimicrobial effects of kordoi (Averrhoa carambola) fruit juice and bamboo (Bambusa polymorpha) shoot extract in pork nuggets. Food Chem, 190: 41-49, doi: 10.1016/ j.foodchem.2015.05.070

Verma AK, Rajkumar V and Suman KM, 2020. Influence of litchi (Litchi chinensis) pericarp powder on quality and storage stability of goat meat nuggets. Indian J Small Ruminants, 20(1): 104-111, doi: 10.5958/0973-9718.2020.00009.4

Zhang N, Chen H, Zhang Y, Ma L and Xu X, 2013. Comparative studies on chemical parameters and antioxidant properties of stipes and caps of shiitake mushroom as affected by different drying methods. J Sci Food Agric, 93(12): 3107-3113, doi: 10.1002/ jsfa. 6151

Received - 11.10.2021, Accepted - 24.11.2021, Published - 01.12.2021

Section Editor: Prof. S. Biswas, Member, Editorial Board 